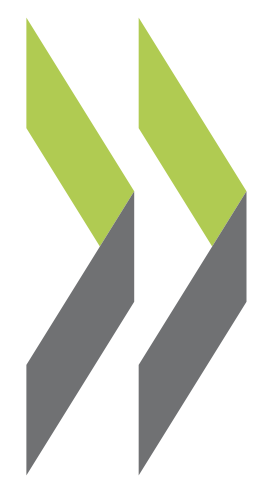

OECD Economics Department Working Papers No. 1682

Are online platforms killing the offline star? Platform diffusion and the productivity of traditional firms

\section{Hélia Costa,}

Giuseppe Nicoletti,

Mauro Pisu,

Christina von Rueden 


\section{ECONOMICS DEPARTMENT}

\section{ARE ONLINE PLATFORMS KILLING THE OFFLINE STAR? PLATFORM DIFFUSION AND THE PRODUCTIVITY OF TRADITIONAL FIRMS}

\section{ECONOMICS DEPARTMENT WORKING PAPERS No. 1682}

By Hélia Costa, Giuseppe Nicoletti, Mauro Pisu and Christina von Rueden

OECD Working Papers should not be reported as representing the official views of the OECD or of its member countries. The opinions expressed and arguments employed are those of the author(s).

Authorised for publication by Luiz de Mello, Director, Policy Studies Branch, Economics Department.

All Economics Department Working Papers are available at www.oecd.org/eco/workingpapers 
OECD Working Papers should not be reported as representing the official views of the OECD or of its member countries. The opinions expressed and arguments employed are those of the author(s).

Working Papers describe preliminary results or research in progress by the author(s) and are published to stimulate discussion on a broad range of issues on which the OECD works.

Comments on Working Papers are welcomed, and may be sent to OECD Economics Department, 2 rue André Pascal, 75775 Paris Cedex 16, France, or by e-mail to eco.contact@oecd.org.

All Economics Department Working Papers are available at www.oecd.org/eco/workingpapers

This document and any map included herein are without prejudice to the status of or sovereignty over any territory, to the delimitation of international frontiers and boundaries and to the name of any territory, city or area.

The statistical data for Israel are supplied by and under the responsibility of the relevant Israeli authorities. The use of such data by the OECD is without prejudice to the status of the Golan Heights, East Jerusalem and Israeli settlements in the West Bank under the terms of international law.

(C) OECD (2021)

You can copy, download or print OECD content for your own use, and you can include excerpts from OECD publications, databases and multimedia products in your own documents, presentations, blogs, websites and teaching materials, provided that suitable acknowledgment of OECD as source and copyright owner is given. All requests for commercial use and translation rights should be submitted to Pubrights@oecd.org 


\section{ABSTRACT / RESUME}

\section{Are online platforms killing the offline star? Platform diffusion and the productivity of traditional firms}

Online platform use has grown remarkably in the last decade. Despite this, our understanding of its implications for economic outcomes is scarce and often limited to case studies and advanced countries. Using a newly built harmonised international dataset of online platforms and their use across 43 countries, covering the 2013-18 period and seven areas of activity, we contribute to filling this gap. Specifically, we investigate whether and under which market conditions platform uptake leads to changes in incumbent firms' productivity. We find that platform use increases labour productivity growth in firms operating in the same sector, and that this takes place through increases in value added growth as opposed to decreases in employment. What is more, productivity gains are greater for small firms and firms in the middle of the productivity distribution, suggesting that online platforms can play an important role in levelling the playing field between SMEs and large companies and in narrowing productivity gaps among firms. Finally, productivity gains are stronger in more dynamic platform markets. Our findings offer insights on factors and policies that can be leveraged to encourage platform development in ways that are beneficial for the economy.

JEL classification codes: D22, D24, O33, O47.

Keywords: Productivity, firm behaviour, online platforms, digitalisation.

\section{Les plateformes numériques entraînent-elles la disparition des bons élèves " hors ligne " ? L'essor des plateformes et la productivité des entreprises traditionnelles}

Les plateformes numériques ont connu un essor remarquable au cours des dix dernières années. Notre compréhension de leurs effets sur les résultats économiques s'avère cependant limitée, les analyses se bornant essentiellement à des études de cas et aux pays avancés. Nous cherchons à combler cette lacune à l'aide d'un nouvel ensemble de données internationales harmonisées sur les plateformes numériques et leur utilisation dans 43 pays et sept secteurs d'activité, sur la période 2013-18. Nous examinons concrètement si, et dans quelles conditions de marché, le recours aux plateformes influe sur la productivité des entreprises en place. Nous constatons que l'utilisation de plateformes stimule les gains de productivité du travail dans les entreprises d'un même secteur, et ce par le biais d'une augmentation de la valeur ajoutée et non d'une diminution de l'emploi. II ressort en outre de notre étude que les petites entreprises et celles situées au milieu de la distribution des niveaux de productivité enregistrent des gains de productivité plus importants, ce qui donne à penser que les plateformes numériques peuvent jouer un rôle crucial dans l'harmonisation des règles du jeu entre les PME et les grandes sociétés, ainsi que dans la réduction des écarts de productivité entre les entreprises. Enfin, il apparaît que les gains de productivité sont plus marqués sur les marchés de plateformes plus dynamiques. Nos observations permettent de mieux comprendre les facteurs et les politiques publiques qui peuvent être mis à profit pour favoriser la diffusion des plateformes d'une manière qui profite à l'économie.

Codes de classification JEL : D22, D24, O33, O47.

Mots clés : productivité, comportement des entreprises, plateformes numériques, digitalisation. 


\section{Table of contents}

\section{Are online platforms killing the offline star? Platform diffusion and the productivity of} traditional firms

2. Data

2.1. Measuring online-platform activity

2.2. Firm-level data

4. Results 14

4.1. Online platforms and firm productivity 14

4.2. Effects by firm size and past productivity levels $\quad 15$

4.3. Platform traffic concentration and persistence of traffic shares 17

4.4. Robustness 18

5. Policy considerations and conclusion $\quad 19$

References 21

Annex A. Additional statistics $\quad 24$

$\begin{array}{lr}\text { Annex B. Further results } & 25\end{array}$

Tables

Table 1. Size of online platform traffic by sector $\quad 11$

Table 2. Correspondence of online platforms' areas into service sectors industrial classification 12

Table 3. Summary statistics $\quad 12$

Table 4. Traffic to online platforms and firm-level productivity growth 14

Table 5. Platform traffic and productivity firms-level growth by firm size 16

Table 6. Platform traffic and firm-level productivity growth by past productivity levels 17

Table A.1. Platforms across areas of activity $\quad 24$

Table A.2. Countries, observations and years used in the firm-level analysis 24

Table B.1. Traffic to online platforms and firm-level productivity growth by sector $\quad 25$

Table B.2. Concentration in the platform market and productivity $\quad 25$

Table B.3. Traffic in other years and firm-level productivity growth 26

Table B.4. The impact of firm-level capital stock $\quad 26$

\section{Figures}

Figure 1. The number of online platforms and their activity have been increasing 10

Figure 2. Total number of unique platforms by sector $\quad 11$

Figure 3. Association of traffic and productivity is not affected by concentration but by persistence 18 
$\operatorname{ECO} / \mathrm{WKP}(2021) 33$ | 5

\section{Boxes}

Box 1. Empirical research on the economic effects of online platforms 


\title{
Are online platforms killing the offline star? Platform diffusion and the productivity of traditional firms
}

\author{
By Hélia Costa, Giuseppe Nicoletti, Mauro Pisu and Christina von Rueden ${ }^{1}$
}

\section{Introduction}

1. In the past decade, online platforms have become ubiquitous. People and firms use them for many purposes, such as entertainment, information, advertisement, and for the purchase and sale of goods and services. The COVID-19 shock has further accelerated the take up of online platforms. During lockdowns, economic activity has shifted towards online marketplaces - at least in those sectors, such as retail sales, mobile payments and restaurant delivery, requiring no or minimal physical contact - helping economies to weather the economic shock (OECD, 2021 $\left.{ }_{[1]}\right)$.

2. The fast diffusion of online platforms over the past decade is attributable to the large economic benefits and opportunities they engender. Large network effects and low-cost transactions allow online platforms to connect more individuals and businesses than physical marketplaces, facilitating market exchanges, while internet openness and global trade enable them to reach users globally. By reducing transaction costs, improving matching of buyers and sellers and boosting capacity utilisation, platforms can increase market efficiency (OECD, 2019 ${ }_{[2]}$; Cramer and Krueger, 2016[3]). The numerous services some online platforms provide to their users (e.g., advanced low-cost logistics and payment services, tailored advertising, better communications with suppliers and easier dispute resolutions) can be especially beneficial for SMEs.

3. At the same time, the rapid rise of online platforms has disrupted well-established industries and business models, and calls for a review of existing regulations across many policy areas, such as competition, labour market, taxation and consumer protection. For instance, large network effects can

\footnotetext{
${ }^{1}$ Corresponding authors: Hélia Costa (helia.costa@oecd.org), Giuseppe Nicoletti (nicolettigiuseppe4@gmail.com), Mauro Pisu (mauro.pisu@oecd.org) and Christina von Rueden (christina.vonrueden@svr-wirtschaft.de). All four authors were in the OECD Economics Department at the time of this work. The authors would like to thank Valentine Millot, Laurence Boone, Luiz de Mello, Alain de Serres, Dan Andrews (all from the OECD Economics Department), Cecilia Jona-Lasinio, Valeria Patella, Silvia Sopranzetti (Italian 2021 G20 Presidency), colleagues from the Centre for Entrepreneurship, SMEs, Regions and Cities, Directorate for Science, Technology, Directorate for Financial and Enterprise Affairs, Directorate for Employment, Labour and Social Affairs, Statistics and Data Directorate, and participants at the G20 Seminar series organised by the Italian G20 Team in preparation to the 2021 G20 Italian Presidency, the OECD applied micro seminar, the Collége de France/Banque de France joint Workshop on Growth, Innovation and Automation, and the University of Minho NIPE seminar for valuable comments. The authors would also like to thank Sarah Michelson Sarfati (also from the OECD Economics Department) for excellent editorial support.
} 
generate winner-take-all dynamics that can result in the emergence of just few large players and lead to rent extraction from users.

4. This study contributes to filling the gap on our understanding of online platforms' effects on economic outcomes in a cross-country, cross-sector setting, by studying the impact of platform use on the productivity of incumbent firms. There are many channels through which online platforms could affect the productivity growth of firms. First, the increase in direct competition caused by disruptor platforms can encourage incumbent firms to innovate more, rising their productivity, or force the exit of less productive firms. Second, aggregator platforms can have a direct impact on incumbent firms' productivity growth by: (i) increasing transparency through review systems, which drives up quality; (ii) enabling firms to improve the efficiency of some of their production processes, such as booking systems and logistics. However, platforms could also contribute to lower the average productivity of incumbent businesses and workers if they create business opportunities for low productivity workers and firms (Schwellnus et al., 2019 ${ }_{[4]}$ ). For instance, by facilitating market access, aggregator platforms may make it easier for small and less productive firms to enter and continue to operate. ${ }^{2}$ Whether the overall association of platform diffusion with productivity is positive or negative is therefore an empirical question.

5. To measure online-platform activity, we use a newly built harmonised international dataset of platform names and use across 28 OECD and G20 countries, covering the 2013-18 period and seven areas of activity (Costa et al. $\left(2021_{[5]}\right)$ ). We merge it with firm-level data in the same countries, activity areas, and years, and investigate whether platform use in a given sector affects the productivity of incumbent firms operating in the same sector. We further analyse whether these impacts depend on characteristics of the firm, such as their size or past productivity, and on features of the platform market in that sector, namely how concentrated an dynamic it is.

6. The focus is on multisided online platforms, defined as those that facilitate interactions between two or more distinct but interdependent sets of users (whether firms or individuals) who interact to exchange goods or services via the Internet. Traffic (i.e. the estimated number of platform website visits) is used as a proxy for the diffusion and penetration of platforms covered by this study. While platforms' website traffic is just an approximation of the actual use of and exchanges within platforms, it has the benefit of being consistent across platforms, countries and over time, providing a first attempt to better assess the diffusion of online platforms in relative terms across countries (OECD, 2018[6]).

7. Previous analyses on the effect of online platforms on firms' economic performance are limited and consist mostly of case studies focusing on specific platforms and settings (see Box 1). By relating directly a proxy of cross-country platform activity to the productivity of traditional firms in the same activity area and country, our approach is closest in spirit to (Bailin Rivares et al., 2019 $\left.{ }_{[7]}\right)$. This study however differs in several key dimensions. We rely on a vastly more comprehensive list of platforms built using different sources, covering also smaller and purely local platforms, and measuring platform activity in absolute (rather than purely relative) terms. The larger set of countries covers economies at different stages of development. We include additional sectors, notably Personal and Professional Services, where online platforms are playing an increasingly important role. We focus on the past decade, when platform diffusion has been most rapid.

8. We find that online platform diffusion is associated with higher productivity growth of incumbent businesses. Results also show that productivity gains are due to increases in value added rather than reductions in employment, pointing to the expansion of business opportunities online platforms generate. Moreover, productivity gains are greater for small firms and firms in the middle of the productivity

\footnotetext{
2 In addition to these channels, online platforms can contribute to increase aggregate productivity by improving allocation efficiency. Increased competition and more transparency may force the least efficient firms to exit and promote the reallocation of market shares towards the most productive ones, a channel that was explored in Bailin Rivares et al. $\left(2019_{[7]}\right)$.
} 


\section{8 | ECO/WKP(2021)33}

distribution, suggesting that online platforms can play an important role in levelling the competitive playing field between SMEs and large companies and in narrowing productivity gaps among firms. Finally, productivity gains are stronger in areas of platform activity with a higher degree of reshuffling among the largest online platforms, underlining the importance of online-platform market contestability for productivity gains. Our results have important policy implications that are addressed in the conclusion.

9. The remainder of the paper is organised as follows. Section 2 describes the new measure of online platform activity and provides details on the firm-level data used. Section 3 sets out the empirical specification and justifies our identification strategy. Finally, Section 4 describes the results, and Section 5 concludes and sets out possible policy areas to be addressed.

\section{Box 1. Empirical research on the economic effects of online platforms}

Despite the vast and growing interest in the development of online platforms and their interactions with economic outcomes, such as prices, profits, and consumer welfare, empirical literature in this area is still relatively scarce, and consists mostly of case studies of specific settings.

In the transport sector, research has mostly focused on the quality of services. Examples are Athey, Castillo and Chandar $\left(2019_{[8]}\right)$, who study which characteristics of Uber services improve their quality, and Wallsten $\left(2015_{[9]}\right)$, who investigates the impact of the uptake of uber in certain United States cities on the ratings of traditional taxi drivers. Similarly, Cramer and Krueger $\left(2015_{[10]}\right)$ compare the efficiency of Uber with that of traditional taxis by measuring capacity utilization in both and find that uber drivers in five U.S. cities have higher capacity utilization rates. Other studies reach similar conclusions (e.g. Rayle et al. $\left.\left(2016_{[11]}\right)\right)$.

In the accommodation sector, studies have focused mostly on the welfare effects of platforms. For example, Zervas, Proserpio and Byers $\left(2017_{[12]}\right)$ quantify the impact of Airbnb on hotel revenues, Barron, Kung and Proserpio $\left(2020_{[13]}\right)$ the increases in rental rates and hotel prices from Airbnb entrance, and Farronato and Fradkin (2018[14] $)$ the changes and distribution of surpluses of consumers, entrants, and incumbents, from Airbnb use, all using United States data.

Again for the United States, Farronato et al. $\left(2020_{[15]}\right)$ study whether ex-ante (in the form of occupational licencing) or ex-post (in the form of online reviews) quality control matters the most to consumers. They use a professional services platform as an example, and find that consumers value mostly the latter.

A considerable amount of work has also focused on job market impacts of online platforms, for example on participation Hall and Krueger $\left(2018_{[16]}\right)$ or on wages Schwellnus et al. $\left(2019_{[4]}\right)$, both for U.S. platforms.

The lack of cross-sector and cross-country empirical studies has to do with the difficulty of measuring platform uptake in a comparable way. Bailin Rivares et al. $\left(2019_{[7]}\right)$ get around the problem by using search data from Google Trends to measure platform uptake across four sectors and ten countries and find a positive relationship between platform uptake and firm-level productivity growth. They find that that aggregator platforms drive this positive effect, lending some support to the second channel described above, and that the positive effect declines with persistent market dominance by a few platforms.

\section{Data}

10. We use yearly data on platform diffusion (proxied by number of visits to online platforms' websites as explained below) across different countries and areas of activity, and yearly firm-level data on value 
added, labour input, productivity and total assets, for firms operating in the same countries and areas of activity.

\subsection{Measuring online-platform activity}

11. The focus of this analysis is on multisided online platforms, defined as those that facilitate interactions between two or more distinct but interdependent sets of users (firms or individuals) who interact to exchange goods or services via the Internet. ${ }^{3}$ This includes both platforms that are in direct competition with incumbent firms (i.e. disruptor platforms) and platforms that connect existing service providers with consumers (i.e. aggregator platforms). The analysis encompasses seven service areas of activity (marketplace to consumers, including consumer-to-consumer and business-to-consumer (X2C), marketplace business-to-business (B2B), restaurant, both booking and delivery, transport/taxi, accommodation, personal services, and professional services) where the diffusion of online platforms has been relevant in recent years.

12. The measurement of online-platform activity is not straightforward, as comparable data across platforms and countries are not available. For this reason, many studies focus on single-platform data. We instead use the estimated number of visits to a platform's website (i.e. traffic) as a proxy for the diffusion of the platform. The assumption is that the number of visits to an online platform's website is correlated with the volume of activity of the platform, either because the platform is accessed directly through the website or because users are looking for information or tips when using the platform through mobile apps. ${ }^{4}$ Unlike data sourced from Google Trends and employed in previous studies, the measure used in this report is not standardised by the total number of Google searches in a country (thus it is not affected by the rising numbers of internet users and changes in the number of Google searches over time) and excludes searches for platforms that did not result in website visits and "false positives" (OECD, 2021 [1]).

13. The data was collected in two steps. First, a list of the most popular platforms across all OECD and $\mathrm{G} 20$ countries in the areas of activity under study was created using a semi-automated process using Crunchbase. ${ }^{5}$ Crunchbase is a company providing information on private and public innovative companies. The information from Crunchbase was complemented with information from OECD country experts and specialised media. In this way, data was collected not only on the largest, most international platforms, but also on smaller and local ones (see Table A.1 in Annex A for examples of platforms across areas of activity). 6

14. Second, to measure diffusion and uptake of online platforms in a consistent way across countries, website traffic data (i.e. the number of visits to online platforms' websites) was collected from Semrush. Semrush is a leading private company that provides, among other services, market information on internet

\footnotetext{
${ }^{3}$ This definition excludes online activities that do not involve online marketplaces, such as e-commerce (direct online sale of own products to customers without third parties) and social media, but it includes third-party business-toconsumers and business-to-business activities.

4 The data does not allow to discern the number of users with mobile apps or how much they use them. Accessing platforms through apps is likely to have surged in recent years, which implies that the data may underestimate the increase in the use of platforms. This also means that the suitability of website traffic as proxy of platform use may vary across activity areas. In some areas (e.g., accommodation) users may be more likely to access online platform services through the website than in others (e.g., transport/taxi).

${ }^{5}$ We do not include Colombia, as it was not an OECD member at the start of this study, nor China, as internet restrictions prevent from collecting data on website traffic.

6 The list of platforms was finalised in early 2020 and contains only the platforms active at that time. As such, the dataset provides no information on exit while it provides information on the date platforms active in 2020 started operating in each country and sector we cover.
} 
traffic to companies' websites. Manual corrections were performed where websites clearly allowed for performing other activities apart from using the platform. More details on the data and their limitations are in Costa et al. (2021 [5] $)$.

15. Over the period of analysis, the number of platforms operating in the 28 countries increased markedly, from 541 in 2013 to 1096 in 2018 . For the 16 countries for which data are available for all years between 2013 and to 2018, the average traffic per capita increased more than threefold (Figure 1, Panel A). The number of platforms also varies widely across countries. For example, the number of active platforms in the United States in 2018 was 773 while it was 114 in Slovenia (Figure 1, Panel B). Costa et al. $\left(2021_{[5]}\right)$ provides further information on the diffusion of platforms across counties and over time.

\section{Figure 1. The number of online platforms and their activity have been increasing}

Panel A: Number of platforms and average of traffic per capita across countries, 2013-2018

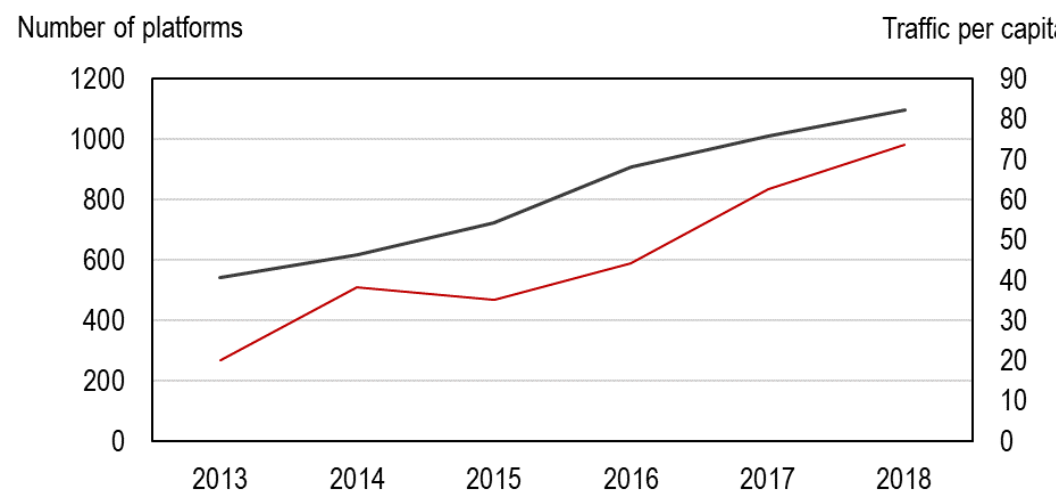

— Total number of platforms (left axis) —Website visits per capita (right axis)

Panel B: Number of platforms in each country in the sample, 2018

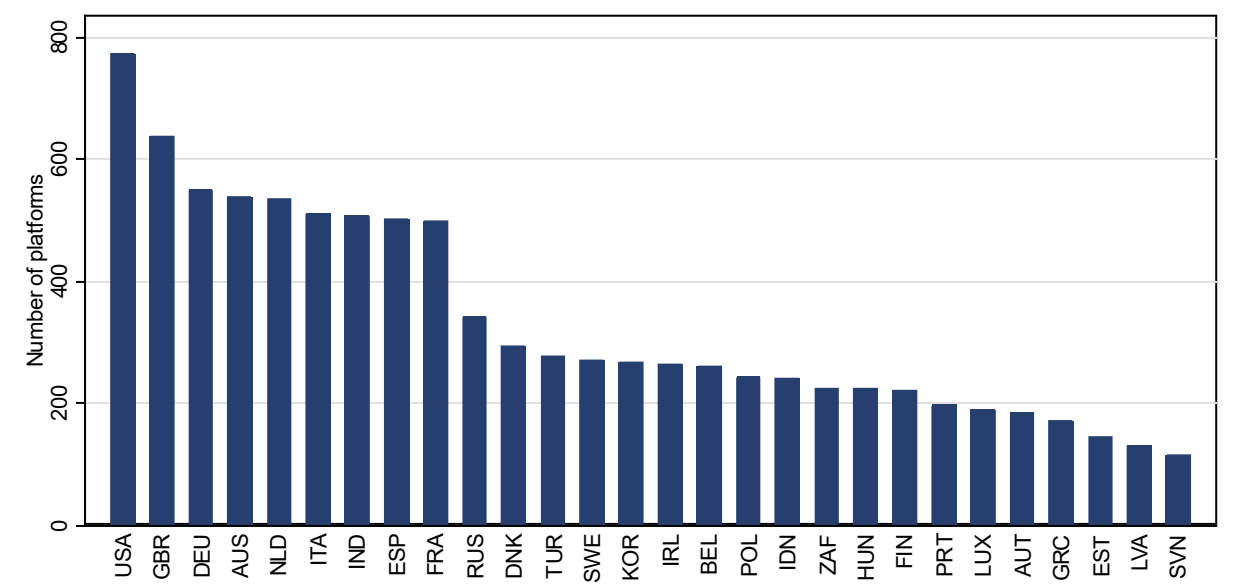

Note: Panel A: The number of platforms refers to the total number of unique online platforms present on the data across all 28 countries used in the analysis; traffic per capita refers to the average of platform website visits per capita across all 16 countries in the database for which data is available from 2013. See Table B.1 in Annex B for a list of countries and the years available. Panel B: the number of platforms is the total number of online platforms present in each of the countries in the sample, in 2018.

Source: Authors's calculations using data from Costa et al. (2021[5]). 
16. Across sectors there are large differences both in the number of platforms and their use. Marketplace to consumers and accommodation are the areas of activity with the largest number of platforms. These two areas are also those with a larger total use (Figure 2), with marketplace to consumers being the largest by far (Table 1). The same activity ranking holds across countries, though with significant variation in absolute numbers by area of activity.

Figure 2. Total number of unique platforms by sector

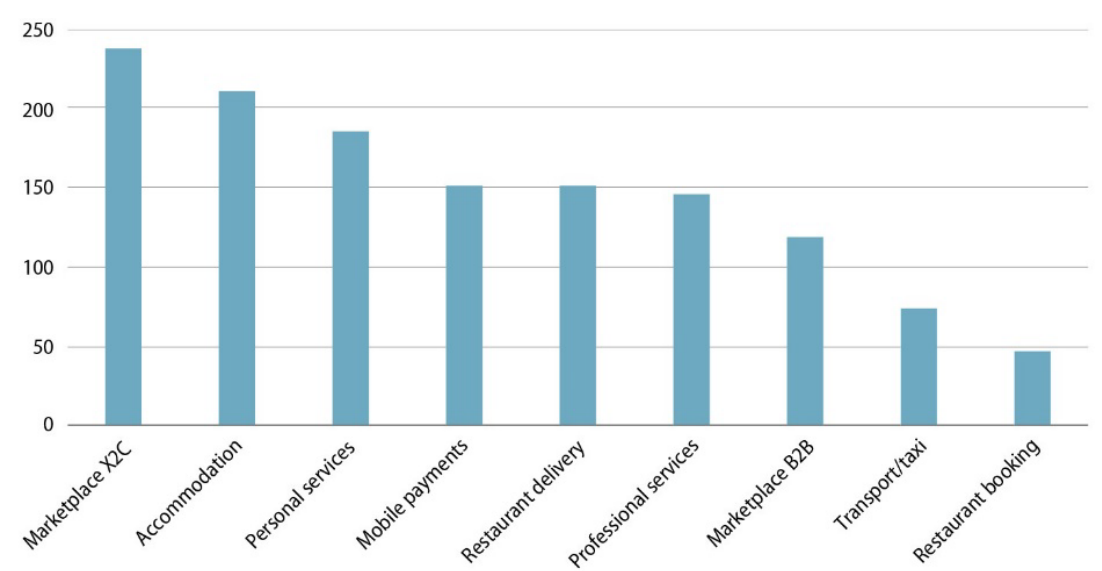

Source: Costa et al. (2021[5]).

Table 1. Size of online platform traffic by sector

Total online platforms' traffic by sector compared to largest sector (Marketplace to Consumers indexed to 100)

\begin{tabular}{l|c|c|c|c|c|c|c}
\hline \multicolumn{1}{c|}{ Year } & 2013 & 2014 & 2015 & 2016 & 2017 & 2018 & 2019 \\
\hline Marketplace to consumers & 100 & 100 & 100 & 100 & 100 & 100 & 100 \\
\hline Accommodation & 3.8 & 4.3 & 4.8 & 4.3 & 5.4 & 6.1 & 6.3 \\
\hline Marketplace (business to business) & 0.3 & 0.3 & 0.3 & 0.3 & 1.1 & 1.7 & 2.1 \\
\hline Mobile Payments & 0.6 & 0.8 & 2.1 & 2.7 & 2.6 & 3.3 & 3.5 \\
\hline Personal Services & 1.4 & 1.8 & 1.9 & 1.7 & 1.9 & 1.9 & 2.0 \\
\hline Professional Services & 0.1 & 0.2 & 0.1 & 0.1 & 0.2 & 0.1 & 0.2 \\
\hline Restaurant Booking & 0.1 & 0.2 & 1.0 & 1.1 & 1.2 & 1.8 & 1.6 \\
\hline Restaurant Delivery & 0.2 & 0.3 & 0.5 & 0.5 & 0.6 & 1.1 & 1.4 \\
\hline Transport/Taxi & 0.3 & 0.4 & 0.5 & 0.6 & 0.6 & 0.8 & 0.8 \\
\hline
\end{tabular}

Source : Costa et al. $\left(2021_{[5]}\right)$.

\subsection{Firm-level data}

17. We then mapped each online platform area of activity into the standard classification (2-digit level in the NACE Rev 2) of services industries (Table 2). The exception was mobile payments sector, as it does not clearly map into any specific standard service industry. For this reason, it was excluded from the analysis. 
Table 2. Correspondence of online platforms' areas into service sectors industrial classification

\begin{tabular}{l|l|l}
\hline Online platforms' activity area & \multicolumn{2}{|l}{ Service sectors (2-dgit NACE Rev 2) } \\
\hline $\begin{array}{l}\text { Marketplace X2C (Consumer-to-consumer } \\
\text { and Business-to-consumer) }\end{array}$ & 47 & Retail trade \\
\hline Marketplace B2B (Business-to-business) & 46 & Wholesale trade \\
\hline Restaurants booking; restaurant delivery & 56 & Food and beverage service activities \\
\hline Transport & 49 & Land transport and transport pipelines \\
\hline Accommodation & 55 & Accommodation \\
\hline Professional services & 62 & Computer programming, consultancy and related activities \\
\hline & 69 & Legal and accounting activities \\
\cline { 2 - 3 } & 71 & Architectural and engineering activities; technical testing and analysis \\
\hline & 73 & Advertising and market research \\
\cline { 2 - 3 } & 74 & Other professional, scientific and technical activities \\
\hline \multirow{2}{*}{ Personal services } & 43 & Specialised construction activities \\
\cline { 2 - 3 } & 81 & Services to buildings and landscape activities \\
\cline { 2 - 3 } & 95 & Repair of computers and personal and household goods \\
\cline { 2 - 3 } & 96 & Other personal service activities \\
\hline
\end{tabular}

18. Firm level data for the same sectors are retrieved from Orbis, a harmonised cross-country firmlevel longitudinal dataset commercialised by Bureau Van Dijk. Orbis provided annual firm-level data until 2018 at the time this study was completed. We follow the process described in Gal $\left(2013_{[17]}\right)$ to clean the data, ensure comparability across countries, and perform imputations for value added that allow to estimate productivity.

19. The study estimates the link between yearly productivity growth of incumbent firms and the activity of online platforms operating in the same country and activity area. The focus is primarily on labour productivity, which is measured as the ratio between real value added and the number of employees. ${ }^{7}$ The empirical analysis covers 28 countries for between two and six years (between 2013 and 2018) depending on the availability of platform and labour productivity data. The cleaned dataset has over 2500000 observations in total, with a large variation across countries (see Table A. 2 in Annex A). ${ }^{8}$ Table 3 presents the main summary statistics.

\section{Table 3. Summary statistics}

\begin{tabular}{l|r|r|r|r|c}
\hline & \multicolumn{1}{|c|}{ Observations } & \multicolumn{1}{c|}{ Average } & Standard deviation & \multicolumn{1}{c|}{ Min } & Max \\
\hline Traffic (billion website visits) & $2,405,271$ & 0.56 & 1.283 & $6.93 \mathrm{e}-06$ & 20.3 \\
\hline Labour Productivity & $2,588,185$ & 10.4 & 0.765 & 2.6 & 20.2 \\
\hline MFP (Wooldridge) & $2,466,768$ & 6.2 & 1.041 & -1.6 & 13.1 \\
\hline MFP (Solow) & $2,433,865$ & 9.7 & 0.776 & 2.4 & 18.7 \\
\hline Value Added & $2,588,185$ & 12.1 & 1.592 & 3.5 & 25.3 \\
\hline Employment & $2,433,383$ & 1.52 & 1.139 & 0 & 11.5 \\
\hline Real per capita stock & $2,515,205$ & 11.2 & 2.282 & 0.2 & 27.1 \\
\hline
\end{tabular}

Note: All variables except for traffic in logs.

\footnotetext{
${ }^{7}$ As alternatives, two measures of multifactor productivity growth are used. These are detailed in Section 3 along with the empirical specification.

8 The main results are robust to restricting the focus on the eight countries with the best coverage.
} 


\section{Empirical specification and identification}

20. We estimate the link between yearly productivity growth and the estimated total number of visits to the websites of online platforms (i.e. our proxy for online platform traffic) operating in the country and activity area matched with the industrial sectors firms belong to. To investigate the link between onlineplatform uptake and firm-level productivity growth, we estimate the following model:

$$
\begin{array}{r}
\Delta \text { Productivity }_{f, s, c, t}=\alpha_{1}+\alpha_{2} \text { Traffic }_{s, c, t-1}+ \\
\alpha_{3} \text { Traffic }_{s, c, t-1}^{2}+\gamma_{f}+\theta_{c t}+\delta_{s t}+\varepsilon_{f, s, c, t}
\end{array}
$$

where $\Delta$ Productivity $_{f, s, c, t}$ is the log change in labour productivity of firm $f$, in sector $s$, country $c$ and in year $t$. Labour productivity is measured as the ratio between real value added and the number of employees. As alternative, we use two measures of multifactor productivity growth. The first is the residual from a Cobb-Douglas constant-returns-to-scale production function, with industry-level labour shares fixed across countries and time but varying across industries, (MFP Solow). The second is based on the semiparametric approach developed by Wooldridge (2009[18]) (MFP Woodridge). For more detail on the computation of productivity see Gal $\left(2013_{[17]}\right)$. Finally, we also use value added and employment as separate dependent variables to identify the source of the productivity changes induced by platform developments.

21. Traffic $c_{s, c, t-1}$ is our main variable of interest. As described in Section 2 above it measures the total number of visits, in billions, to all platform websites operating in sector $s$, country $c$, in year $t-1$. Table 1 in Section 2 presents the summary statistics for the main variables of interest. We also include the square of Traffic to account for possible non-linearities. These could arise as platforms could initially have large positive effects on productivity growth as firms access new markets more easily and invest in digitalization, but these may have decreasing marginal returns. It can additionally capture possible cross-sector heterogeneity of the association between online platform traffic and productivity growth. Finally, $\gamma_{f}, \theta_{c t}$, and $\delta_{s t}$ are, respectively, firm, country-year, and sector-year fixed effects; and $\varepsilon_{f, s, c, t}$ is the error term. ${ }^{9}$

22. The rich set of fixed effects is included to control for time-invariant firm-specific characteristics (like management characteristics or country and industry specific characteristics), time-varying country-specific trends (such as trends in internet use or smartphone penetration), and global sectoral changes (for example driven by technological innovation).

23. Despite these controls, some possible endogeneity issues remain. First, excluded variables that are sector and country specific (such as demand shocks or sectoral policies/regulations) could affect both traffic and productivity. However, as we use traffic lagged by one year, this shock would need to be persistent over time to introduce endogeneity biases. Second, there could be a problem of reverse causality, if platforms tend to enter sectors and grow more easily when sectors are booming and thus firms in these sectors are more productive, introducing an upward bias in our estimation. We focus only on within-firm changes, lowering the likelihood of this problem. However, to further investigate this issue, we introduce as an explanatory variable traffic in years $t$ and $t+1$. Our results (Table B. 3 in Annex B) indicate that if anything, we might have the opposite effect: platforms might tend to enter more sectors that are less productive, and so our estimates of their effect on productivity should be regarded as a lower bound.

24. In order to understand how dynamism in the platform market affects the relationship between platform use and productivity growth of incumbent firms, equation (1) is augmented with a term $C_{t-1, c, s}$. The variable $C_{t-1, c, s}$ is in turn the degree of concentration (measured as the share of traffic of top 8 platforms in each sector, country, and year), and the degree of persistence (measured as the amount of top 8 firms

\footnotetext{
${ }^{9}$ Our results are unchanged when controlling for firm-level characteristics, such as the level of total assets. These results are available upon request.
} 
that were already in the top 8 in the previous year, in each sector, country, and year). The equation to be estimated thus becomes:

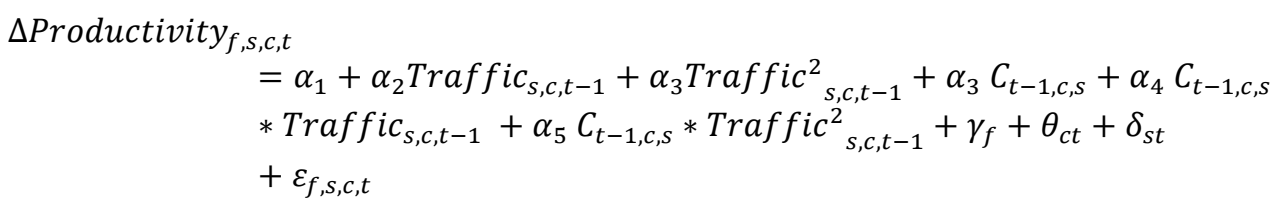

25. We estimate model (1) and its extension (2) through OLS using the methodology for linear models with multi-way fixed effects developed by Correia $\left(2016_{[19]}\right)$. We adjust standard errors by two-way clustering, at the firm level and at the country-industry-year level.

\section{Results}

\subsection{Online platforms and firm productivity}

26. The coefficient estimates suggest that online platform traffic has a positive and concave relationship with labour productivity growth (Table 4, column 1). As online platforms develop the positive effect of traffic on firms productivity becomes weaker. ${ }^{10}$ According to these estimates, an increase in traffic of one standard deviation is associated with an increase of labour productivity growth by around 5.3 percentage points. For instance, going from the average traffic level observed in Spain to that of France would raise average firm-level productivity growth of incumbent firms by 2.1 percentage points. Columns (2) and (3) show that the impact of traffic on MFP growth is qualitatively similar but quantitatively smaller than that on labour productivity as part of the improvement in labour productivity could be attributable to higher investment. Overall, these results are consistent with those of Bailin Rivares et al. $\left(2019_{[7]}\right)$.

Table 4. Traffic to online platforms and firm-level productivity growth

\begin{tabular}{|c|c|c|c|c|c|}
\hline & (1) & (2) & (3) & (4) & (5) \\
\hline Dependent variable & Labour productivity & MFP (Solow) & MFP (Woold.) & Value Added & Labour \\
\hline \multirow{2}{*}{ Traffict $-1_{1}$} & $0.04435^{* * *}$ & $0.02683^{* * *}$ & $0.02913^{* * *}$ & $0.04118^{* * *}$ & -0.00264 \\
\hline & $(0.011)$ & $(0.010)$ & $(0.010)$ & $(0.010)$ & $(0.006)$ \\
\hline \multirow[t]{2}{*}{$\operatorname{Traffic}^{2} t-1$} & $-0.00326^{\star \star *}$ & $-0.00201^{* * *}$ & $-0.00215^{\star \star *}$ & $-0.00301^{* \star *}$ & 0.00021 \\
\hline & $(0.001)$ & $(0.001)$ & $(0.001)$ & $(0.001)$ & $(0.000)$ \\
\hline \multirow[t]{2}{*}{ Constant } & $0.01156^{\star \star \star}$ & $0.01859^{* \star *}$ & $0.02196^{\star \star \star}$ & $0.04141^{* * *}$ & $0.02898^{* * *}$ \\
\hline & $(0.004)$ & $(0.004)$ & $(0.004)$ & $(0.004)$ & $(0.002)$ \\
\hline Observations & $2,321,795$ & $2,234,111$ & $2,186,429$ & $2,326,966$ & $2,248,277$ \\
\hline R-squared & 0.211 & 0.237 & 0.220 & 0.302 & 0.267 \\
\hline $\mathrm{F}$ & 8.467 & 3.702 & 4.583 & 8.249 & 0.149 \\
\hline
\end{tabular}

Note: The dependent variables are the log change in each of the variables. All estimations include firm, country-year, and sector-year fixed effects. Standard errors clustered at the firm and country-sector-year.

Source: Authors' estimations with data from Orbis, Semrush, and Crunchbase.

27. Interestingly, the last two columns of Table 4 suggest that the productivity gains associated with increases in online platform traffic are generated by growth in value added, while employment does not

\footnotetext{
10 The point estimates however suggest that the curvature of the relationship between traffic and firms' productivity growth is not pronounced and the marginal effect of traffic with respect to productivity growth remains roughly constant for most of the traffic levels and it only starts decreasing after the $80^{\text {th }}$ traffic's percentile.
} 
seem to be affected. Access to services provided by online platforms, such as logistics, marketing, tailored advertising, dispute resolutions and other factors could make it easier to reach new clients and improve service quality, boosting firms revenues at unchanged labour input. These results are in line with findings that 6.8 per cent of value added in German industry and industry-related services depends substantially on the use of platforms (vbw, 2019[20]).

28. These aggregate results hide some variation across sectors. Results by sector, obtained by interacting the traffic variable with sector dummies (see Table B.1 in Annex B), show that the results hinge mostly on a positive association of productivity with traffic in two activity areas: marketplace to consumers and transport. In other areas the association is not significant at conventional levels. Also, the results show that the non-linearity found at the aggregate level is generated by sector heterogeneity. ${ }^{11}$ Thus, we control for non-linearity in all further aggregate specifications so as to better capture the cross-sector heterogeneity of the association between online platform traffic and productivity growth. The sectoral heterogeneity of the diffusion-productivity nexus likely reflects differences in platform penetration (with marketplace to consumers dwarfing all the other areas), differences in platform maturity (e.g. B2B platforms are often just beginning to disrupt the wholesale retail market) ${ }^{12}$ and differences in platform characteristics (with disruptors and aggregators being unequally distributed across platform activity areas).

\subsection{Effects by firm size and past productivity levels}

29. The positive association of online platform diffusion with productivity growth is likely to differ across firms based on their management and employee skills, organizational capital, intangible assets and in general the capacity of firms to innovate and thrive in a new environment. These features are, however, either not reported or poorly reported in the Orbis database. For this reason, we focus on two observable characteristics that are likely to be correlated with them -- size and productivity levels - and repeat the estimation of model (1) by distinguishing effects at different levels of the size and productivity distribution of firms.

30. The results point to a positive and significant association between platform traffic and labour productivity growth that is decreasing in these two firm characteristics. Table 5 presents the marginal effects of platform traffic on firms' productivity growth for firms in six employment brackets (lagged by one year). The association is significant and sizeable for firms with up to 100 employees. ${ }^{13}$ In firms with less than ten employees, one standard deviation increase in traffic is associated with a boost of more than 10 percentage points to their labour productivity growth. For instance, going from the average traffic level observed in Spain to that of France would raise the average productivity growth of a small incumbent firm (less than 10 employees) operating in the same activity area by 5.5 percentage points.

\footnotetext{
${ }^{11}$ We initially included in the regression the squared term of traffic but it was either insignificant or adding very little information (the coefficient was very small and affected the marginal effects of traffic only for very large traffic values). Thus, the concavity of overall traffic is mostly driven by cross-sectoral heterogeneity in the association of traffic with firms' productivity growth.

12 Online platforms operating in the B2B are considerably less developed than in the retail and consumer markets but are developing fast. They cover a variety of businesses processes, including the purchase and sale of components and goods that are usually intermediated by wholesalers as well as logistics, management of inventories, cloud computing and other IT and non IT related services for corporates. By facilitating connections and market transactions between companies, B2B online platforms can disrupt traditional wholesale business models by undermining their intermediator role.

${ }^{13}$ While the lack of significance might be partly due to smaller sample sizes for larger firms, the smaller coefficients might also be indicative of a smaller impact on larger firms.
} 
Table 5. Platform traffic and productivity firms-level growth by firm size

\begin{tabular}{l|c|c|c|c|c|c}
\hline & $(1)$ & $(2)$ & $(3)$ & $(4)$ & $(5)$ & $(6)$ \\
\hline Size & {$[1,10[$} & {$[10,50[$} & {$[50,100[$} & {$[100,250[$} & {$[250,1000[$} & {$[1000, \max ]$} \\
\hline & & & & & & \\
\hline Traffic $t-1$ & $0.12095^{\star * *}$ & $0.07083^{\star * *}$ & $0.06061^{* *}$ & 0.05686 & 0.01870 & -0.07368 \\
\hline Traffic $^{2} t-1$ & $(0.025)$ & $(0.018)$ & $(0.027)$ & $(0.041)$ & $(0.022)$ & $(0.063)$ \\
\hline & $-0.01125^{* * *}$ & $-0.00758^{* * *}$ & $-0.00404^{* *}$ & -0.00429 & -0.00180 & 0.00187 \\
\hline Constant & $(0.003)$ & $(0.002)$ & $(0.002)$ & $(0.003)$ & $(0.001)$ & $(0.002)$ \\
\hline & $-0.02979^{* * *}$ & -0.00185 & $-0.02149^{*}$ & -0.02261 & -0.00144 & $0.12081^{*}$ \\
\hline Observations & $(0.009)$ & $(0.006)$ & $(0.012)$ & $(0.018)$ & $(0.012)$ & $(0.073)$ \\
\hline R-squared & $1,369,918$ & 330,666 & 24,661 & 15,122 & 6,569 & 1,074 \\
\hline F & 0.200 & 0.227 & 0.279 & 0.292 & 0.308 & 0.418 \\
\hline
\end{tabular}

Note: The dependent variable is the log change of labour productivity. All estimations include firm, country-year, and sector-year fixed effects. Standard errors clustered at the firm and country-sector-year. Traffic is platform activity measured in billion visits to all platforms' website in a given sector.

Source: Authors' calculations with data from Orbis, Semrush and Crunchbase.

31. The large estimated impact of online platforms traffic on small and medium sized firms' productivity growth may result from the large benefits small surviving firms can reap from network effects, access to larger markets and services that online platforms offer or simply from tougher competition. Easy access to additional customers and services provided by online platforms (such as logistics for Marketplace to Consumers) could for instance have a positive impact on the growth of value added without the need for additional labour input. An analysis of the impacts of online platforms on value added and employment growth corroborates these hypotheses, as small firms' value added increases and labour input decreases as digital-platform traffic rises. Additional regressions disaggregated by sector show this is true mostly for the sectors of Marketplace to Consumers, Professional services, and Transport. Overall these findings indicate that online platforms can play an important role in helping SMEs to overcome barriers that have been hampering their growth. ${ }^{14}$

32. As regards productivity, results point to a positive association between online-platform traffic and labour productivity growth across the whole firm-level productivity distribution but for the least productive firms, with the strength of the effect declining in productivity levels (Table 6). ${ }^{15}$ Productivity gains are particularly large for firms whose productivity is around the median. Conversely, effects for the least and most productive firms are weak. The former may not benefit from online platforms traffic as they might lack the absorptive capacity (e.g. in terms of organisational capital or skills) to improve efficiency in response to increased competition (Berlingieri et al., 2020 [21]]); the latter may have less scope to further improve productivity merely due to online platforms' operations as for them product and process innovation, R\&D spending and investment in other intangibles are more important drivers of productivity. All in all, these results suggest that platform diffusion can be a powerful lever for facilitating productivity catch up of laggard firms to frontier levels.

\footnotetext{
14 This is in line with findings that while on average in Germany 6.8 per cent of value added in industry and industryrelated services is reliant on the use of platforms, for SMEs this figure increases to 8.3 per cent (vbw, 2019 [20]).

${ }^{15}$ Labour productivity classes are defined for each sector and year and labour productivity is lagged by two years to diminish the risk of endogeneity bias. Results using once-lagged productivity remain similar.
} 
Table 6. Platform traffic and firm-level productivity growth by past productivity levels

\begin{tabular}{|c|c|c|c|c|}
\hline & (1) & (2) & (3) & (4) \\
\hline Productivity percentile & {$[0,25$ th [} & [25th,50th[ & [50th,75th[ & {$[75$ th, 100$]$} \\
\hline \multirow{2}{*}{ Traffic $_{t-1}$} & -0.06478 & $0.07509^{* * *}$ & $0.06843^{* * *}$ & $0.02952^{*}$ \\
\hline & $(0.063)$ & $(0.023)$ & $(0.020)$ & $(0.016)$ \\
\hline \multirow[t]{2}{*}{$\operatorname{Traffic}^{2} t-1$} & -0.00189 & $-0.00498^{* * *}$ & $-0.00552^{\star * *}$ & -0.00212 \\
\hline & $(0.005)$ & $(0.002)$ & $(0.002)$ & $(0.001)$ \\
\hline \multirow[t]{2}{*}{ Constant } & $0.12720^{* \star \star}$ & 0.00411 & $-0.02654^{* * *}$ & $-0.04522^{* \star *}$ \\
\hline & $(0.011)$ & $(0.008)$ & $(0.009)$ & $(0.006)$ \\
\hline Observations & 127,122 & 190,464 & 257,963 & 351,606 \\
\hline R-squared & 0.271 & 0.254 & 0.249 & 0.231 \\
\hline $\mathrm{F}$ & 3.700 & 5.519 & 6.066 & 1.793 \\
\hline
\end{tabular}

Note: The dependent variable is the log change of labour productivity. All estimations include firm, country-year, and sector-year fixed effects. Standard errors clustered at the firm and country-sector-year. Traffic is platform activity measured in billion visits to all platforms' website in a given sector.

Source: Authors' calculations with data from Orbis, Semrush and Crunchbase.

\subsection{Platform traffic concentration and persistence of traffic shares}

33. Network effects are a crucial feature of online platforms Invalid source specified.. They imply that new users tend to use platforms that are already large, thus increasing their size further. In principle, network effects are welfare enhancing, as they allow for connecting more individuals and businesses than physical marketplaces, and facilitate market exchanges, thus increasing the efficiency of market matching and growth. At the same time network effects can give rise to winner-take-all dynamics that can result in the emergence of few dominant players, weakening competition and leading to rent extraction.

34. The effects of platform traffic on incumbents' productivity might depend on the structure of the platform market. A priori, it is not clear whether a more concentrated industry would be more or less efficient. On the one hand, there could be efficiency gains to having very large platforms, stemming primarily from better supply-demand matches due to network effects.

35. On the other hand, more concentration could lead dominant platforms to abuse their market power and to rent extraction, which could lower observed productivity of incumbent firms. For instance, dominant online platforms can increase the prices advertisers (many of the small businesses) pay, thereby increasing costs, reducing output, and diverting income towards platforms. Or they could be in a position to impose unilaterally changes to contractual conditions regulating the access to and use of the platform that are onerous to users Invalid source specified.. In addition, dominant online platforms selling goods or services in competition with third party sellers on the platform may benefit from what has been labelled a "kill zone". This is the combination of two platform advantages. First, their ability to use the information they collect as platform operators to identify and copy (at low cost) the best performing products/services. Second, their capacity to steer consumers towards their products/services and away from the original ones through tailored ads and ranking results of searches on the platform (OECD, 2020[22]). Factors potentially leading to lower productivity outcomes for incumbents are likely to gain importance in markets where the dominance of large platforms remains unchallenged over time.

36. Our results, obtained including sector-country-year traffic concentration and platform persistence measures in aggregate regressions interacted with traffic, suggest that it is not traffic concentration per se but the persistence of top market shares that affects the association of platform traffic with productivity. ${ }^{16}$ Figure 3 reports the changes in the relationship between traffic and productivity by degree of online

16 These results are consistent with Bailin Rivares et al. $\left(2019_{[7]}\right)$. 
platforms' traffic concentration and turnover at the top. Specifically, in panel A, we focus on traffic concentration, measured by the share of traffic of the top 8 platforms (CR8). In panel B, we focus on persistence, as measured by the share of top 8 firms that remain at the top in the following year.

\section{Figure 3. Association of traffic and productivity is not affected by concentration but by persistence}

A. Marginal impact of traffic on productivity growth by percentile of traffic concentration (CR8)

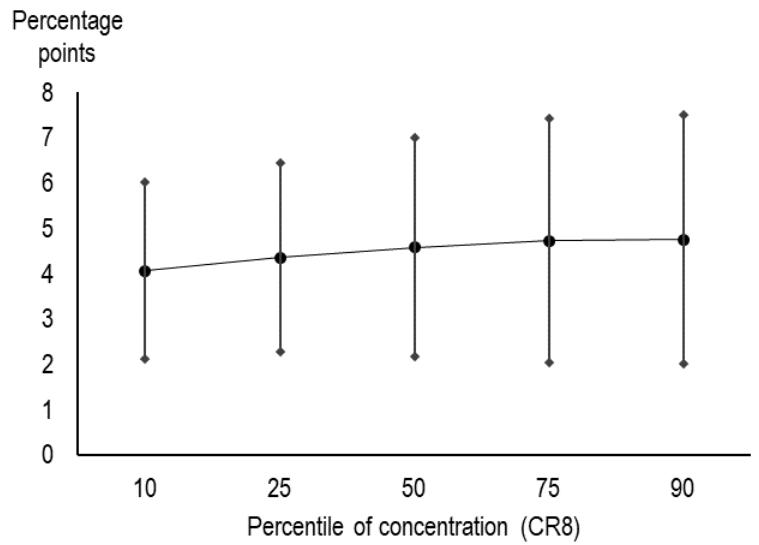

B. Marginal impact of traffic on productivity growth by degree of persistence of largest platforms in the sector

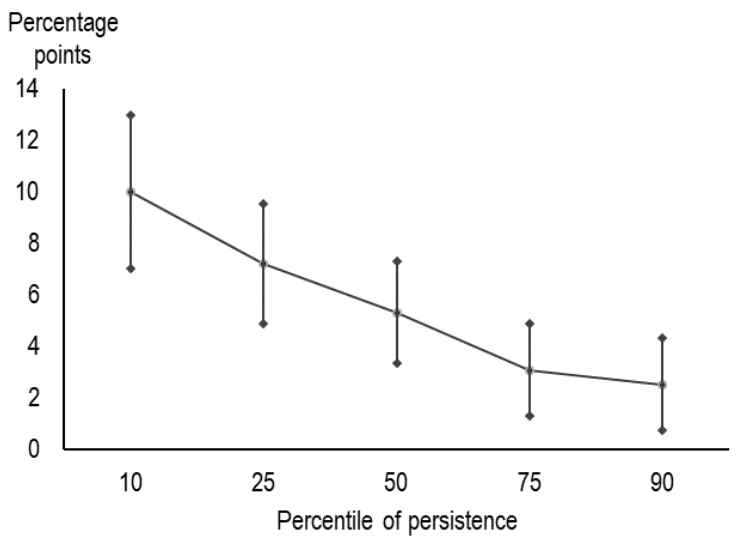

Note: Estimated marginal effects evaluated at the average traffic are represented by the middle dots. Lines represent $95 \%$ confidence intervals. Margimal effects are estimated with the following regression: $\Delta$ Productivity $_{f, s, c, t}=\alpha_{1}+\alpha_{2}$ Traffic $_{s, c, t-1}+\alpha_{3}$ Traffic $^{2}{ }_{s, c, t-1}+$ $\alpha_{3} C_{t-1, c, s}+\alpha_{4} C_{t-1, c, s} *$ Traffic $_{s, c, t-1}+\alpha_{5} C_{t-1, c, s} *$ Traffic $^{2}{ }_{s, c, t-1}+\gamma_{f}+\theta_{c t}+\delta_{s t}+\varepsilon_{f, s, c, t}$. The variable $C_{t-1, c, s}$ is in turn the degree of concentration (measured as the share of traffic of top 8 platforms in each sector, country, and year), and the degree of persistence (measured as the amount of top 8 firms that were already in the top 8 in the previous year, in each sector, country, and year). Full regression in columns (2) and (3) of Table B.2 of Annex B.

Source: Authors' estimations with data from Orbis, Semrush, and Crunchbase.

37. According to our estimates, lack of turnover among the largest online platforms weakens the positive association between traffic and productivity while traffic concentration per se does not significantly affect the association of online platform activity with productivity growth. These results are robust to different measures of concentration and persistence (see Table B.2 in Annex B). However, the measure of concentration used in this study (online platforms' website traffic) is only a proxy of actual platforms' market shares. Based on this proxy, the results indicate that in a more dynamic activity area (one with less persistence and more reshuffling of platforms at the top) incumbent firms stand to benefit more in terms of productivity growth from platform diffusion. This further highlights the need for policies to ensure online platform markets remain open and contestable.

\subsection{Robustness}

38. We conducted a series of sensitivity tests to verify the robustness of the baseline findings to alternative specifications and to the presence of endogeneity issues.

39. First, as set out in Section 3, there could be a problem of reverse causality, if platforms tend to enter sectors and grow more easily when sectors are booming and thus firms in these sectors are more productive, because these sectors attract more attention, investment, or more productive workers. This would introduce an upward bias in our estimation. To investigate this issue, we introduce as an explanatory variables traffic in years $t$ and $t+1$. If this hypothesis were true, then the leads of our main independent variable, that is, the future traffic, would be positive and statistically significant. 
40. The results are presented in columns (1)-(4) of Table B.3 in Annex B. They show that there is a negative and statistically significant coefficient for the variable measuring traffic in the years $t$ and $t+1$. This indicates that we might have reverse causality but with the opposite effect as expected: platforms might tend to enter and develop quicker in sectors that were initially more depressed, for example because there are larger opportunities to improve sales or productivity. In this case, our estimates of the effect of traffic on productivity should be interpreted as a lower bound of the true effect.

41. Second, while most of the confounding, firm-specific variables that might be related with productivity are captured by the firm fixed effects, firm investment and the resulting capital stock could have an impact on the productivity growth of firms. Therefore, we repeat our regressions including firms' real capital stock, adjusted by PPP, in thousands, lagged by one period. While this variable is often statistically significant, it does not change any of the results significantly. The main results are presented in Table B.4 in Annex B.

42. Finally, and because both platform traffic and productivity growth might be increasing over time simultaneously, generating correlation without causality, we also include a time trend, for each countrysector, in the analysis. The results (column (5) of Table B.3 in Annex B) show that our main results do not change with the inclusion of this variable.

\section{Policy considerations and conclusion}

43. Despite their rising importance in modern economies, debates surrounding online platforms have been mired in a paradoxical situation: although online platforms are adept at collecting and exploiting vast quantity of data, available data on their operations, diffusion and impacts on economies and societies are scarce and inconsistent. National accounts poorly capture the economic activities taking places in digital marketplaces (OECD, 2018 $\left.{ }_{[6]}\right)$ and policy discussions are often based on anecdotal evidence and selected data released by online platforms themselves.

44. This paper contributes to policy discussions surrounding the economic impacts of online platforms. We merge a new harmonised international dataset of global and local platforms across 26 countries and 7 activity areas, covering the 2013-18 period, with firm-level data on the same areas. We use these new data to investigate the impact of online platforms on the productivity of firms operating in the same activity areas, with positive significant impacts. We further investigate the distribution of the impacts across firms of different features and across platform market characteristics, namely concentration and dynamism. We find that the positive impacts of platform activity are felt mainly for smaller firms and those in the middle of the productivity distribution, and that market dynamism, in the form of lower persistence of platforms in the top in terms of traffic, enhances these gains.

45. One implication of our results is that the design of regulations affecting online platforms should take into consideration, in addition to other important issues (such as labour relation, taxation, or data privacy), the impact online platforms have on productivity, especially of small and less productive firms. Online platforms could be especially beneficial in economies where SMEs account for a large share of output and jobs - such as in emerging economies but also in several developed ones such as Greece, Italy, Spain and Germany - as they can contribute to enhance business dynamism and growth.

46. The large productivity benefits online platforms can generate for SMEs point to the need to pay specific attention to the skills of workers and managers of small firms, who often have less (or lack altogether) formal qualifications than those in larger enterprises. For example, companies in Germany identify shortage of skilled labour as a deterrent for offering and developing online platforms and other digital business models (vbw, 2019[20]). For SMEs, using platforms is less demanding in terms of skills than other digital technologies, and many larger platforms offer free online courses and tutorials catered specifically to SMEs. However, in order to take full advantage of online platforms, they need adequate 
internal digital processes requiring investment in basic digital and organisational skills (OECD, 2021 [23]). Strengthening lifelong learning systems and on-the-job professional training schemes is key to enabling upskilling or reskilling throughout life especially in view of new technological developments.

47. Policy also needs to ensure that the welfare gains arising from network effects - generated by activity concentrating in few large platforms - go hand in hand with those arising from strong competition among online platforms. That the productivity benefits arising from online platforms tend to rise with the degree of reshuffling among top platforms calls for ensuring that online-platform markets remain open and contestable. Provisions to limit lock-in effects could strengthen market contestability without undermining the large benefits of network effects of successful online platforms (OECD, 2019[24]).

48. To this end, removing barriers hampering the ability of users to switch platforms or use multiple platforms at the same time (multihoming) could avoid lock-in effects. This would involve supporting user data (e.g., information, reputation, ratings) portability and interoperability of platforms (e.g. through open application programming interfaces), and prohibiting contractual clauses limiting multihoming. In this sense, the General Data Protection Regulation (GDPR), which formally introduced the right to data portability for individuals in the European Union, could be a powerful tool to strengthen competition. Singapore also introduced data portability obligation in legislation with the 2019 Personal Data Protection Commission (OECD, 2020[25]).

49. The proliferation of different data-privacy regulations across countries however risks fragmenting the international regulatory landscape, raising costs for companies, generating uncertainty and undermining trust in the digital economy. This is particularly relevant for SMEs, which often lack the skills to assess the risks from their sharing of data (OECD, 2021 [23]). This calls for more international coordination (OECD, 2020[25]). The common adoption of advanced privacy-enhancing solutions, like homomorphic encryption, which enables the processing of encrypted data without revealing its embedded information, can help share data while ensuring privacy (OECD, 2019[24]). Given the global nature of many platforms, international efforts to agree on common standards can facilitate data portability and interoperability across platforms while ensuring data privacy and security.

50. Specific aspects of online platforms' business model warrant the review of competition policies and their enforcement mechanisms. These aspects concern, for instance, the collection of large quantity of data and the use of algorithms to exploit them, the acquisition of smaller platforms to ward off potential threats (i.e. killer acquisitions), direct competition with the third party sellers using the platform (OECD, 2018[26]). Several countries (such as France, Germany, Italy, Japan and the United Kingdom) have commissioned studies of existing competition policy frameworks to determine which changes are needed (if any). Although the exact findings of each of these studies vary, countries agreed that digital markets represent a unique challenge for competition policy, and that other policy areas, such as consumer protection and data privacy, also have a role to play to preserve competition (OECD, 2016 [27]; OECD, $2020_{[28]}$ ). Other concerns regard the opportunity of regulating algorithms and what effects such regulations could have on competition and innovation (OECD, 2017[29]).

51. There is a need to ensure a level-playing field between online platforms and their users. In this respect the European Commission has recently put forward, after thorough stakeholder consultations, the Digital Markets Act and the Digital Services Act to reset the digital regulatory framework and to support SMEs in their scaling-up process through better access to customers and lower compliance costs (European Commission, 2020[30]). These proposals are currently being discussed within the EU. Other concrete changes currently being mooted (although more controversial) include the introduction of a new digital regulator, new enforcement approaches (e.g. a greater use of interim measures to enable more timely responses to potentially anticompetitive conduct) and new merger notification requirements (Mancini, 2019[31]; Mancini, 2019[32]). 


\section{References}

Athey, S., J. Castillo and B. Chandar (2019), "Service Quality in the Gig Economy: Empirical Evidence about Driving Quality at Uber", SSRN Electronic Journal, http://dx.doi.org/10.2139/ssrn.3499781.

Bailin Rivares, A. et al. (2019), "Like it or not? The impact of online platforms on the productivity of incumbent service providers", OECD Economics Department Working Papers, No. 1548, OECD Publishing, Paris, https://dx.doi.org/10.1787/080a17ce-en.

Barron, K., E. Kung and D. Proserpio (2020), The Effect of Home-Sharing on House Prices and Rents: Evidence from Airbnb, https://ssrn.com/abstract=3006832 (accessed on 2 September 2020).

Berlingieri, G. et al. (2020), "Laggard firms, technology diffusion and its structural and policy determinants", OECD Science, Technology and Industry Policy Papers, No. 86, OECD Publishing, Paris, https://dx.doi.org/10.1787/281bd7a9-en.

Correia, S. (2016), A Feasible Estimator for Linear Models with Multi-Way Fixed Effects *.

Costa, H. et al. (2021), "Welcome to the (digital) jungle: a new cross-country measure of online platform diffusion", OECD Economics Department Working Papers, No. 1683, OECD Publishing, Paris.

Cramer, J. and A. Krueger (2016), Disruptive change in the taxi business: The case of uber, American Economic Association, http://dx.doi.org/10.1257/aer.p20161002.

Cramer, J. and A. Krueger (2015), "Disruptive Change in the Taxi Business: The Case of Uber", National Bureau of Economic Research, http://dx.doi.org/10.3386/w22083.

European Commission (2020), Europe fit for the Digital Age: Commission proposes new rules for digital platforms, Press Release, https://ec.europa.eu/commission/presscorner/detail/en/ip 202347.

Farronato, C. and A. Fradkin (2018), "The Welfare Effects of Peer Entry in the Accommodation Market: The Case of Airbnb", National Bureau of Economic Research Working Paper Series, http://dx.doi.org/10.3386/w24361.

Farronato, C. et al. (2020), "Consumer Protection in an Online World: An Analysis of Occupational Licensing", National Bureau of Economic Research Working Paper Series, Vol. No. 26601, http://dx.doi.org/10.3386/w26601. 
Gal, P. (2013), "Measuring Total Factor Productivity at the Firm Level using OECD-ORBIS", ECO/WKP(2013)41, http://www.oecd.org/eco/Workingpapers (accessed on 21 July 2020).

Hall, J. and A. Krueger (2018), "An Analysis of the Labor Market for Uber's Driver-Partners in the United States", ILR Review, Vol. 71/3, pp. 705-732, http://dx.doi.org/10.1177/0019793917717222.

Mancini, J. (2019), Charting the way forward for digital competition policy, https://oecdonthelevel.com/2019/12/02/charting-the-way-forward-for-digital-competitionpolicyl (accessed on 26 January 2021).

Mancini, J. (2019), "Digital antitrust: An emerging consensus?", https://www.concurrences.com $\mathrm{N}^{\circ} 4-2019$, pp. 0-0.

Marketplace Pulse (2020), Amazon's Retail Business Is Now Just $50 \%$ of the Company's Revenue, https://www.marketplacepulse.com/articles/amazons-retail-business-is-now-just-50of-the-companys-revenue (accessed on 19 June 2020).

OECD (2021), The Digital Transformation of SMEs, OECD Studies on SMEs and Entrepreneurship, OECD Publishing, Paris, https://doi.org/10.1787/bdb9256a-en.

OECD (2021), The Role of Digital Platforms in Weathering the COVID-19 Shock, OECD Policy Responses to Coronavirus (COVID-19), http://www.oecd.org/coronavirus/policyresponses/the-role-of-online-platforms-in-weathering-the-covid-19-shock-2a3b8434/.

OECD (2020), Consumer Data Rights and Competition - Background Note, OECD Publishing, Paris, https://www.oecd.org/daf/competition/consumer-data-rights-and-competition.htm (accessed on 30 August 2020).

OECD (2020), OECD Digital Economy Outlook 2020, OECD Publishing, Paris, https://dx.doi.org/10.1787/bb167041-en.

OECD (2020), Start-ups, Killer Acquisitions and Merger Control, http://www.oecd.org/daf/competition/start-ups-killer-acquisitions-and-merger-control.htm (accessed on 9 September 2020).

OECD (2019), An Introduction to Online Platforms and Their Role in the Digital Transformation, OECD Publishing, Paris, https://dx.doi.org/10.1787/53e5f593-en.

OECD (2019), Enhancing Access to and Sharing of Data: Reconciling Risks and Benefits for Data Re-use across Societies, OECD Publishing, Paris, https://dx.doi.org/10.1787/276aaca8en.

OECD (2019), Measuring the Digital Transformation: A Roadmap for the Future, OECD Publishing.

OECD (2019), OECD Employment Outlook 2019: The Future of Work, OECD Publishing, Paris, https://dx.doi.org/10.1787/9ee00155-en.

OECD (2019), OECD Skills Outlook 2019 : Thriving in a Digital World, OECD Publishing, Paris, https://dx.doi.org/10.1787/df80bc12-en.

OECD (2018), Measuring online platforms and cloud computing in National Accounts. 
OECD (2018), Rethinking Antitrust Tools for Multi-Sided Platforms 2018, OECD Publishing, https://www.oecd.org/daf/competition/rethinking-antitrust-tools-for-multi-sided-platforms.htm.

OECD (2017), Algorithms and Collusion: Competition Policy in the Digital Age, http://www.oecd.org/competition/algorithms-collusion-competition-policy-in-the-digitalage.htm.

OECD (2016), Big Data: Bringing Competition Policy to the Digital Era, OECD, https://one.oecd.org/document/DAF/ COMP(2016)14/en/pdf.

Rayle, L. et al. (2016), "Just a better taxi? A survey-based comparison of taxis, transit, and ridesourcing services in San Francisco", Transport Policy, Vol. 45, pp. 168-178, http://dx.doi.org/10.1016/..tranpol.2015.10.004.

Schwellnus, C. et al. (2019), "Gig economy platforms: Boon or Bane?", OECD Economics Department Working Papers, No. 1550, OECD Publishing, Paris, https://dx.doi.org/10.1787/fdb0570b-en.

vbw (2019), Plattformen - Infrastruktur der Digitalisierung, http://www.vbw-bayern.de/ (accessed on 4 December 2020).

Wallsten, S. (2015), The Competitive Effects of the Sharing Economy: How is Uber Changing Taxis?.

Wooldridge, J. (2009), "On estimating firm-level production functions using proxy variables to control for unobservables", Economics Letters, Vol. 104/3, pp. 112-114, http://dx.doi.org/10.1016/j.econlet.2009.04.026.

Zervas, G., D. Proserpio and J. Byers (2017), "The Rise of the Sharing Economy: Estimating the Impact of Airbnb on the Hotel Industry", Journal of Marketing Research, Vol. 54/5, pp. 687705, http://dx.doi.org/10.1509/jmr.15.0204.

Zhu, F. and M. Iansiti (2019), Why Some Platforms Thrive and Others Don't, https://hbr.org/2019/01/why-some-platforms-thrive-and-others-dont (accessed on 7 July 2020). 


\section{Annex A. Additional statistics}

Table A.1. Platforms across areas of activity

\begin{tabular}{rcccc}
\hline \multicolumn{1}{c}{ Area } & Number of & \multicolumn{2}{c}{ Examples } \\
\cline { 5 - 5 } \cline { 4 - 4 } platforms & & Present in many countries & Present in one or few countries \\
Accommodation & 210 & & airbnb, booking & lastminute-cottages, triverna \\
Marketplace B2B & 115 & & alibaba, indiamart & buyinportugal, luxalia \\
Marketplace X2C & 241 & & amazon, ebay & storesquare, trucadao \\
Mobile Payments & 150 & & paypal, rakuten & vindi, zoomit \\
Personal Services & 185 & & treatwell, taskrabbit & yad2, grupinis \\
Professional Services & 147 & & upwork, freelancer & crowdguru, belancer \\
Restaurant Booking & 46 & & opentable, zomato & luxtable, lunchgate \\
Restaurant Delivery & 149 & & deliveroo, ubereats & clickdelivery, aptit \\
Transport/Taxi & 85 & & bolt, uber & apptaxi, m-o-v \\
\hline
\end{tabular}

Note: Some platforms are present in more than one area (e.g. rakuten is present in marketplace to consumer, mobile payments and accommodation; uber is present in transport and restaurant delivery, etc.) so the sum of platforms by area is larger than the total number of unique platforms.

Source: Costa et al. $\left(2021_{[5]}\right)$

Table A.2. Countries, observations and years used in the firm-level analysis

\begin{tabular}{l|l|l}
\hline Country & Observations & Years \\
\hline Australia & 2,792 & $2013-2018$ \\
\hline Austria & 2,618 & $2016-2018$ \\
\hline Belgium & 50,384 & $2013-2018$ \\
\hline Denmark & 6,459 & $2013-2018$ \\
\hline Estonia & 28,068 & $2016-2017$ \\
\hline Finland & 119,916 & $2013-2018$ \\
\hline France & 522,206 & $2013-2018$ \\
\hline Germany & 24,339 & $2013-2018$ \\
\hline Greece & 27 & $2016-2017$ \\
\hline Hungary & 291,689 & $2015-2018$ \\
\hline India & 809 & $2015-2018$ \\
\hline Ireland & 5,367 & $2013-2018$ \\
\hline Indonesia & 115 & $2016-2018$ \\
\hline Italy & 942,061 & $2013-2018$ \\
\hline Korea (Republic of) & 43,179 & $2016-2018$ \\
\hline Latvia & 1,682 & $2016-2017$ \\
\hline Luxembourg & 666 & $2016-2018$ \\
\hline Netherlands & 1,460 & $2013-2018$ \\
\hline Poland & 38,285 & $2013-2018$ \\
\hline Portugal & 303,743 & $2016-2018$ \\
\hline Russian Federation & 160 & $2013-2018$ \\
\hline Slovenia & 42,777 & $2016-2017$ \\
\hline South Africa & 74 & $2016-2018$ \\
\hline Spain & $1,129,206$ & $2013-2018$ \\
\hline Sweden & 401,605 & $2013-2018$ \\
\hline Turkey & 133 & $2013-2018$ \\
\hline United Kingdom & 71,474 & $2013-2018$ \\
\hline United States of America & 1,182 & $2013-2018$ \\
\hline Total & $4,032,476$ & - \\
\hline & & \\
\hline
\end{tabular}




\section{Annex B. Further results}

Table B.1. Traffic to online platforms and firm-level productivity growth by sector

\begin{tabular}{l|c|c|c|c|c}
\hline & $(1)$ & $(2)$ & $(3)$ & $(4)$ & $(5)$ \\
\hline Dependent variable: & Labour productivity & MFP (Solow) & MFP (Woold.) & Value Added & Labour \\
\hline Accommodation & 0.15832 & 0.18158 & 0.19816 & 0.20057 & 0.05467 \\
\hline Marketplace B2B & $(0.123)$ & $(0.119)$ & $(0.125)$ & $(0.126)$ & $(0.061)$ \\
\hline & -0.18330 & -0.14871 & -0.23384 & $-0.35723^{*}$ & $-0.16797^{*}$ \\
\hline Marketplace X2C & $(0.138)$ & $(0.144)$ & $(0.150)$ & $(0.201)$ & $(0.089)$ \\
\hline & $0.00830^{* *}$ & 0.00616 & 0.00566 & $0.01010^{* *}$ & 0.00192 \\
\hline Personal Services & $(0.004)$ & $(0.004)$ & $(0.004)$ & $(0.004)$ & $(0.002)$ \\
\hline & -0.12217 & -0.05304 & -0.07760 & -0.03914 & $0.08668^{*}$ \\
\hline Professional Services & $(0.089)$ & $(0.082)$ & $(0.080)$ & $(0.095)$ & $(0.047)$ \\
\hline & 1.57519 & $2.53020^{*}$ & 0.84384 & $4.09560^{* * *}$ & $2.91015^{* * *}$ \\
\hline Restaurant & $(1.311)$ & $(1.293)$ & $(0.876)$ & $(1.256)$ & $(0.665)$ \\
\hline & 0.15450 & 0.33004 & 0.27200 & 0.29089 & 0.11448 \\
\hline Transport/Taxi & $(0.303)$ & $(0.268)$ & $(0.278)$ & $(0.310)$ & $(0.171)$ \\
\hline & $1.81757^{* * *}$ & $1.93304^{* * *}$ & $1.91088^{* * *}$ & $2.41098^{* * *}$ & 0.27717 \\
\hline Constant & $(0.627)$ & $(0.632)$ & $(0.576)$ & $(0.740)$ & $(0.963)$ \\
\hline & $0.02366^{* * *}$ & $0.02365^{* *}$ & $0.02903^{* * *}$ & $0.04950^{* * *}$ & $0.02370^{* * *}$ \\
\hline & $(0.003)$ & $(0.003)$ & $(0.003)$ & $(0.003)$ & $(0.002)$ \\
\hline Observations & & & & & \\
\hline R-squared & $2,321,795$ & $2,234,111$ & $2,186,429$ & $2,321,795$ & $2,173,109$ \\
\hline F & 0.211 & 0.237 & 0.220 & 0.301 & 0.263 \\
\hline
\end{tabular}

Note: The dependent variables are the log change in each of the variables. Sectors indicate traffic in each sector in year t-1. All estimations include firm, country-year, and sector-year fixed effects. Standard errors clustered at the firm and country-sector-year.

Source: OECD calculations with data from Orbis, Semrush and Crunchbase.

Table B.2. Concentration in the platform market and productivity

\begin{tabular}{|c|c|c|c|c|}
\hline & (1) & $(2)$ & (3) & (4) \\
\hline Concentration measure: & CR8 & CR4 & Persistence & Reshuffling \\
\hline \multirow[t]{2}{*}{ Traffict-1 } & -0.02738 & 0.04793 & $0.30105^{\star \star *}$ & $0.04730^{\star \star *}$ \\
\hline & $(0.107)$ & $(0.036)$ & $(0.045)$ & $(0.017)$ \\
\hline \multirow[t]{2}{*}{ Concentration measure } & -0.02439 & $0.13230^{\star \star \star}$ & 0.00301 & $0.05516^{* *}$ \\
\hline & $(0.078)$ & $(0.045)$ & $(0.005)$ & $(0.026)$ \\
\hline \multirow[t]{2}{*}{ Traffict-1x Concentration } & 0.07893 & -0.01203 & $-0.04388^{* * *}$ & $0.08538^{\star *}$ \\
\hline & $(0.117)$ & $(0.040)$ & $(0.007)$ & $(0.036)$ \\
\hline \multirow[t]{2}{*}{ Traffic2t-1 } & 0.00512 & 0.00140 & $-0.04332^{* * *}$ & $-0.00351^{* * *}$ \\
\hline & $(0.011)$ & $(0.004)$ & $(0.008)$ & $(0.001)$ \\
\hline \multirow[t]{2}{*}{ Traffic2t-1x Concentration } & -0.00910 & -0.00533 & $0.00668^{\star * *}$ & $-0.02510^{* * *}$ \\
\hline & $(0.011)$ & $(0.004)$ & $(0.001)$ & $(0.008)$ \\
\hline \multirow[t]{2}{*}{ Constant } & 0.03383 & $-0.10234^{\star * *}$ & 0.00115 & 0.00038 \\
\hline & $(0.076)$ & $(0.039)$ & $(0.026)$ & $(0.007)$ \\
\hline Observations & $2,321,795$ & $2,321,795$ & $2,321,795$ & $1,891,009$ \\
\hline R-squared & 0.211 & 0.211 & 0.211 & 0.236 \\
\hline
\end{tabular}




\begin{tabular}{l|l|l|l|l}
\hline $\mathrm{F}$ & 3.653 & 6.510 & 9.640 & 5.769 \\
\hline
\end{tabular}

Note: The dependent variable is the log change in labour productivity. All estimations include firm, country-year, and sector-year fixed effects. Standard errors clustered at the firm and country-sector-year.

Source: OECD calculations with data from Orbis, Semrush and Crunchbase.

Table B.3. Traffic in other years and firm-level productivity growth

\begin{tabular}{|c|c|c|c|c|c|}
\hline & (1) & (2) & (3) & (4) & (5) \\
\hline \multirow[t]{2}{*}{ Traffic $\mathrm{t}-1$} & $0.04435^{\star * *}$ & & & $0.04922^{* * *}$ & $0.04261^{* * *}$ \\
\hline & $(0.011)$ & & & $(0.013)$ & $(0.011)$ \\
\hline \multirow[t]{2}{*}{ Traffic $^{2} \mathrm{t}-1$} & $-0.00326^{\star \star *}$ & & & $-0.00403^{* * *}$ & $-0.00315^{\star \star \star}$ \\
\hline & $(0.001)$ & & & $(0.001)$ & $(0.001)$ \\
\hline \multirow[t]{2}{*}{ Traffic $t$} & & $-0.02308^{\star * *}$ & & -0.00432 & \\
\hline & & $(0.008)$ & & $(0.014)$ & \\
\hline \multirow[t]{2}{*}{ Traffic $^{2} t$} & & $0.00130^{* *}$ & & $-0.00170^{*}$ & \\
\hline & & $(0.001)$ & & $(0.001)$ & \\
\hline \multirow[t]{2}{*}{ Traffic ${ }_{t+1}$} & & & $-0.03285^{* * *}$ & $-0.03601^{* * *}$ & \\
\hline & & & $(0.008)$ & $(0.010)$ & \\
\hline \multirow[t]{2}{*}{ Traffic ${ }^{2}{ }_{t+1}$} & & & $0.00270^{* * *}$ & $0.00434^{* * *}$ & \\
\hline & & & $(0.001)$ & $(0.001)$ & \\
\hline \multirow[t]{2}{*}{ Trend } & & & & & -0.00024 \\
\hline & & & & & $(0.000)$ \\
\hline \multirow[t]{2}{*}{ Constant } & $0.01156^{* * *}$ & $0.03600^{* * *}$ & $0.03535^{\star * *}$ & $0.02861^{* * *}$ & 1.71485 \\
\hline & $(0.004)$ & $(0.003)$ & $(0.003)$ & $(0.009)$ & $(1.159)$ \\
\hline Observations & $2,321,795$ & $2,954,592$ & $2,596,220$ & $1,451,834$ & $2,321,795$ \\
\hline R-squared & 0.211 & 0.187 & 0.178 & 0.221 & 0.211 \\
\hline
\end{tabular}

Note: The dependent variable is the log change in labour productivity. All estimations include firm, country-year, and sector-year fixed effects. Standard errors clustered at the firm and country-sector-year.

Source: OECD calculations with data from Orbis, Semrush and Crunchbase.

Table B.4. The impact of firm-level capital stock

\begin{tabular}{|c|c|c|c|c|c|}
\hline & (1) & (2) & (3) & (4) & (5) \\
\hline Dependent variable & Labour productivity & MFP (Solow) & MFP (Woold.) & Value Added & Labour \\
\hline \multirow[t]{2}{*}{ Traffic $t-1$} & $0.04406^{* * *}$ & $0.02767^{\star * *}$ & $0.02967^{\star \star *}$ & $0.04088^{* * *}$ & -0.00224 \\
\hline & $(0.011)$ & $(0.010)$ & $(0.010)$ & $(0.010)$ & $(0.006)$ \\
\hline \multirow[t]{2}{*}{ Traffic $^{2} \mathrm{t}-1$} & $-0.00325^{\star \star *}$ & $-0.00206^{\star \star *}$ & $-0.00220^{\star * *}$ & $-0.00300^{* * *}$ & 0.00018 \\
\hline & $(0.001)$ & $(0.001)$ & $(0.001)$ & $(0.001)$ & $(0.000)$ \\
\hline \multirow[t]{2}{*}{ Capital ${ }_{t-1}$} & $0.00000^{*}$ & $0.00000^{\star *}$ & $0.00000^{* * *}$ & 0.00000 & $-0.00000^{\star * *}$ \\
\hline & $(0.000)$ & $(0.000)$ & $(0.000)$ & $(0.000)$ & $(0.000)$ \\
\hline \multirow[t]{2}{*}{ Constant } & $0.01164^{* \star *}$ & $0.01826^{* * *}$ & $0.02176^{* * *}$ & $0.04152^{* * *}$ & $0.02885^{\star \star *}$ \\
\hline & $(0.004)$ & $(0.004)$ & $(0.004)$ & $(0.004)$ & $(0.002)$ \\
\hline Observations & $2,315,125$ & $2,193,145$ & $2,164,577$ & $2,320,276$ & $2,241,933$ \\
\hline R-squared & 0.211 & 0.240 & 0.222 & 0.302 & 0.267 \\
\hline
\end{tabular}

Note: The dependent variable is the log change in labour productivity. All estimations include firm, country-year, and sector-year fixed effects. Standard errors clustered at the firm and country-sector-year.

Source: OECD calculations with data from Orbis, Semrush and Crunchbase. 